\title{
PROBLEM ZGODNOŚCI UNORMOWAŃ DOTYCZĄCYCH PRZECHOWYWANIA DOKUMENTACJI PŁACOWEJ I OSOBOWEJ PRACODAWCÓW Z KONSTYTUCJĄ RZECZYPOSPOLITEJ POLSKIEJ
}

\begin{abstract}
Abstrakt: Celem opracowania jest podjęcie dyskusji w zakresie konstytucyjności wybranych regulacji składających się na system przechowywania dokumentacji płacowej i osobowej. Zagadnienie to ma istotne znaczenie nie tylko teoretyczne, lecz także praktyczne. W opracowaniu uwzględniono wytyczne wynikające z raportu Najwyższej Izby Kontroli oraz sformułowano postulaty zmian.
\end{abstract}

Słowa kluczowe: Konstytucja Rzeczypospolitej Polskiej z 2 kwietnia 1997 roku, dokumentacja płacowa i osobowa pracowników, prawo do zabezpieczenia społecznego.

1. Ratio długookresowego przechowywania dokumentacji pracowniczej jest przede wszystkim zapewnienie możliwości jej wykorzystania do ustalania podstawy wymiaru emerytury, renty lub innych świadczeń wypłacanych przez Zakład Ubezpieczeń Społecznych (dalej: ZUS), jak również w postępowaniu sądowym w sprawach ze stosunku pracy ${ }^{1}$. Materia ta ma istotne znaczenie z punktu widzenia skutecznego dochodzenia przysługujących jednostce praw z tytułu zabezpieczenia społecznego. Dlatego też powstaje zasadne pytanie o konstytucyjność przepisów składających się na system przechowywania dokumentacji płacowej i osobowej pracowników².

${ }^{1}$ Informacja Najwyższej Izby Kontroli o wynikach kontroli: Skuteczność działania systemu przechowywania dokumentacji osobowej i płacowej, Warszawa, wrzesień 2017, s. 5, LGD.410.018.2016, nr ewid. 118/2017/P/16/064/LGD, https://www.nik.gov.pl/plik/id,15248,vp,17729.pdf (dostęp: 9.11.2019); zob. też na przykład uzasadnienie do rządowego projektu ustawy o zmianie niektórych ustaw w związku ze skróceniem okresu przechowywania akt pracowniczych oraz ich elektronizacją, druk sejmowy nr 1995, VIII kadencja, http://www.sejm.gov.pl/Sejm8.nsf/druk.xsp?nr=1995 (dostęp: 19.10.2019).

2 Zob. A. Bisztyga, Opinia prawna nt. zgodności z Konstytucja Rzeczypospolitej Polskiej z dnia 2 kwietnia 1997 roku (Dz.U. z 1997r. Nr 78, poz. 483 z późń. zm.), w szczególności z jej artykułem 67 ust. 1 i artykułem 32 ust. 1, paragrafu 28 ust. 1 rozporzadzenia Ministra Pracy i Polityki 
W niniejszym opracowaniu podjęta zostanie próba oceny — z perspektywy unormowań Konstytucji Rzeczypospolitej Polskiej z dnia 2 kwietnia 1997 roku, to jest zasady równości (art 32 ust. 1 Konstytucji RP) oraz prawa jednostki do zabezpieczenia społecznego (art. 67 ust. 1 Konstytucji RP) - $\$ 28$ ust. 1 rozporządzenia Ministra Pracy i Polityki Społecznej z 11 października 2011 roku w sprawie postępowania o świadczenia emerytalno-rentowe ${ }^{4}$ (dalej: rozporządzenie MPiPS w sprawie postępowania o świadczenia emerytalno-rentowe). Uregulowanie to tworzy, oprócz przepisów rozdziału 4a i 4b ustawy z dnia 14 lipca 1983 roku o narodowym zasobie archiwalnym i archiwach (dalej: ustawa o narodowym zasobie archiwalnym i archiwach) ${ }^{5}$, podstawy prawne ustalania wymiaru emerytury, renty lub innych świadczeń wypłacanych przez ZUS oraz postępowania sądowego w sprawach ze stosunku pracy.

W $\S 21$ ust. 1 rozporządzenia MPiPS w sprawie postępowania o świadczenia emerytalno-rentowe określono, że:

środkiem dowodowym stwierdzającym wysokość wynagrodzenia, dochodu, przychodu oraz uposażenia przyjmowanego do ustalenia podstawy wymiaru emerytury lub renty są zaświadczenia pracodawcy lub innego płatnika składek, legitymacja ubezpieczeniowa lub inny dokument, na podstawie którego można ustalić wysokość wynagrodzenia, dochodu, przychodu lub uposażenia ${ }^{6}$.

\section{Ponadto}

środkiem dowodowym w postępowaniu przed organem rentowym mogą być również poświadczone za zgodność z oryginałem kopie dokumentów stwierdzających stan zdrowia oraz dotyczących okresów składkowych i nieskładkowych, a także wysokości wynagrodzenia, przychodu, dochodu i uposażenia przyjmowanego do ustalenia podstawy wymiaru świadczeń, wydawane przez jednostki upoważnione do przechowywania dokumentacji zlikwidowanych lub przekształconych zakładów pracy ${ }^{7}$.

\section{W orzecznictwie podkreśla się, że}

w postępowaniu przed organem rentowym nie jest możliwe udowadnianie wysokości wynagrodzenia innymi dowodami niż wymienione we wskazanych wyżej przepisach dokumenty. Przepisy regulujące postępowanie o świadczenia emerytalno-rentowe przed organem rentowym nie mają natomiast zastosowania w postępowaniu sądowym, które regulowane jest przepisami Kodeksu

Społecznej z dnia 11 października 2011 roku w sprawie postepowania o świadczenia emerytalno-rentowe (Dz.U. z 2011r. Nr 237, poz. 1412) w świetle rozdziatu 4 a i 4 b ustawy z dnia 14 lipca 1983 roku o narodowym zasobie archiwalnym i archiwach (Dz. U. z 2016 r. poz. 1506 z późn. zm.), sporządzona dla Departamentu Prawnego i Orzecznictwa Kontrolnego Najwyższej Izby Kontroli, Warszawa 2017.

3 Dz.U. z 1997 r. Nr 78, poz. 483 ze zm.

4 Dz.U. z 2011 r. Nr 237, poz. 1412.

5 Tekst jedn. Dz.U. z 2019 r. poz. 553 ze zm.

${ }^{6}$ W orzecznictwie zob. np. wyrok SA w Białymstoku z 11 czerwca 2018 roku, III AUa 243/18, LEX nr 2550327.

$7 \S 28$ ust. 1 rozporządzenia MPiPS w sprawie postępowania o świadczenia emerytalno-rentowe. 
postępowania cywilnego, a ewentualne ograniczenia dowodowe mogą wynikać jedynie z przepisów tego Kodeksu. Oznacza to, że fakty, od których uzależnione jest prawo do emerytury oraz wysokość tego świadczenia, mogą być wykazywane wszelkimi środkami dowodowymi przewidzianymi w Kodeksie postępowania cywilnego, w tym także zeznaniami świadków ${ }^{8}$.

Przykładowo Sąd Okręgowy w Warszawie w uzasadnieniu do wyroku z dnia 15 marca 2019 roku $^{9}$, odwołując się do orzecznictwa Sądu Najwyższego ${ }^{10}$, podkreślił, że

w postępowaniu cywilnym przed sądem pracy i ubezpieczeń społecznych w sprawie o przeliczenie wysokości emerytury możliwe jest dopuszczenie i przeprowadzenie wszelkich dowodów, w tym także dowodu z zeznań świadków lub przesłuchania samego wnioskodawcy. Tymczasem dla celów obliczenia wysokości emerytury organ rentowy musi dysponować pewnymi danymi co do wysokości dochodów ubezpieczonego stanowiących podstawę obliczenia wysokości świadczeń emerytalnych. Wprawdzie w postępowaniu cywilnym sąd nie jest związany takimi ograniczeniami $\mathrm{w}$ dowodzeniu, jakie odnoszą się do organu rentowego w postępowaniu rentowym, jednak ustalenia dokonywane przez sąd muszą być oparte na konkretnych dowodach.

2. Z perspektywy konstytucyjnej wątpliwości budzi szczególnie przywoływany $\S 28$ ust. 1 rozporządzenia MPiPS w sprawie postępowania o świadczenia emerytalno-rentowe. Przepis ten stanowi, że:

środkiem dowodowym w postępowaniu przed organem rentowym mogą być również poświadczone za zgodność z oryginałem kopie dokumentów stwierdzających stan zdrowia oraz dotyczących okresów składkowych i nieskładkowych, a także wysokości wynagrodzenia, przychodu, dochodu i uposażenia przyjmowanego do ustalenia podstawy wymiaru świadczeń, wydawane przez jednostki upoważnione do przechowywania dokumentacji zlikwidowanych lub przekształconych zakładów pracy.

Redakcja $§ 28$ ust. 1 rozporządzenia MPiPS w sprawie postępowania o świadczenia emerytalno-rentowe, jak również zdeterminowana nią praktyka odpowiednich instytucji rodzi skutek w postaci nierównego traktowania różnych kategorii podmiotów uprawnionych do zabezpieczenia społecznego. Redakcja wspomnianego przepisu, a w konsekwencji jego interpretacja, przynosi podział uprawnionych do zabezpieczenia społecznego na takich, którzy mają możliwość udokumentowania podstawy świadczenia, oraz na takich, którym możliwość ta została ograniczona albo wręcz została ona zlikwidowana. Wynika to z tego, że kwestionowany przepis cechuje brak konstytucyjnie wymaganej, „należytej określoności”.

Wskazany $\S 28$ ust. 1 rozporządzenia MPiPS w sprawie postępowania o świadczenia emerytalno-rentowe dopuszcza możliwość interpretacji tego przepisu w sposób niezgodny w szczególności z zasadą równości oraz z prawem do zabezpie-

8 Wyrok SA w Łodzi - III Wydział Pracy i Ubezpieczeń Społecznych z 6 marca 2013 roku, III AUa 1148/12, Legalis nr 1033727.

9 Wyrok WSO Warszawa-Praga w Warszawie z 15 marca 2019 roku, VII U 372/18, LEX nr 2701469.

10 Wyrok SN z 4 lipca 2007 roku, I UK 36/07, LEX nr 390123. 
czenia społecznego, albowiem praktyka stosowania tego przepisu sytuuje w mniej korzystnej pozycji pewną kategorię osób, to jest byłych pracowników zlikwidowanych zakładów pracy, zwłaszcza małych niepublicznych podmiotów, którzy mają — wobec nienależytego funkcjonowania systemu przechowywania dokumentacji płacowej i osobowej - utrudnienia w ustaleniu miejsca przechowywania dokumentacji, w przeciwieństwie do pracowników podmiotów istniejących, a także nieistniejących już podmiotów o charakterze publicznym, w wypadku których uzyskanie kopii dokumentów, nawet $\mathrm{w}$ razie likwidacji lub przekształcenia tych podmiotów, nie stwarza problemów. Należy podkreślić, że poszkodowani z powodu niemożności udokumentowania podstawy prawa do świadczenia z tytułu zabezpieczenia społecznego znaleźli się w niekorzystnej sytuacji bez własnej winy.

Omawiany problem prawny dotyczy sytuacji społecznie wrażliwej, w której obywatel ma prawo oczekiwać od organów władzy publicznej należytej dbałości i staranności w działaniu na rzecz należytego zabezpieczenia przedmiotowej dokumentacji. Taki obowiązek wynika już z preambuły Konstytucji RP, która stanowi o rzetelnym i sprawnym działaniu instytucji publicznych. Wymaga to po stronie władz publicznych podejmowania wielu działań, w tym dążenia, aby administracja publiczna była elastyczna i zdolna do wewnętrznych zmian ${ }^{11}$. Możemy wówczas mówić o realizacji prawa do dobrej administracji, które jest istotnym europejskim standardem statusu jednostki ${ }^{12}$.

3. Oczekiwanie to znajduje odbicie i wyraża się przede wszystkim w doniosłym elemencie konstytucyjnej zasady demokratycznego państwa prawnego, którym jest zasada zaufania do państwa. Jego odpowiednikiem po stronie organów prawodawczych jest wymóg w postaci zasady przyzwoitej legislacji. Zgodnie z nią przepisy powinny być tworzone w taki sposób, aby umożliwić ich jednolitą wykładnię oraz stosowanie ${ }^{13}$. Niejasność (niejednoznaczność) przepisu często wprowadza niepewność sytuacji prawnej adresata normy ze względu na pozostawienie organom stosującym prawa do ich wykładni. To zaś prowadzi do różnicowania indywidualnych rozstrzygnięć, a w konsekwencji do postrzegania prawa jako niesprawiedliwego, oraz do utraty zaufania obywateli do państwa ${ }^{14}$. Zasada przyzwo-

11 Zob. B. Przywora, Normatywny model przesadowej nieodpłatnej pomocy prawnej w Polsce, Warszawa 2019, s. 13-14; zob. też L. Bielecki, Prawo do dobrej administracji jako wzmocnienie efektywności ochrony praw człowieka i obywatela w Unii Europejskiej, [w:] Europejski system ochrony praw człowieka. Aksjologia - instytucje - efektywność, red. J. Jaskiernia, Torun 2015, s. $192-193$.

12 Zob. B. Przywora, op. cit., s. 14; zob. także G. Kryszeń, Państwo rzetelne i sprawne jako idea konstytucyjnego ustroju Rzeczypospolitej Polskiej, [w:] Zagadnienia prawa konstytucyjnego. Polskie i zagraniczne rozwiazania ustrojowe. Księga jubileuszowa dedykowana Profesorowi Dariuszowi Góreckiemu w siedemdziesiąta rocznicę urodzin, red. K. Skotnicki, K. Składkowski, A. Michalak, Łódź 2016, s. 263. Na temat prawa do dobrej administracji szerzej zob. też A. Jackiewicz, Prawo do dobrej administracji jako standard europejski, Torun 2008.

13 Wyrok TK z 17 maja 2005 roku, P 6/04, OTK ZU 5A/2005, poz. 50.

14 Wyrok TK z 20 listopada 2002 roku, K 41/02, OTK ZU 6A/2002, poz. 83. 
itej legislacji zakłada zakaz stanowienia przepisów niejasnych, wieloznacznych, niepozwalających jednostce przewidzieć skutki prawne jej zachowań ${ }^{15}$. Z zasadą poprawnej legislacji wiąże się bezpośrednio zasada określoności. Wynika z niej obowiązek konstruowania przepisów poprawnie z punktu widzenia zarówno językowego, jak i logicznego ${ }^{16}$.

W komentowanym przypadku nie została zachowana zasada przyzwoitej legislacji, ponieważ część obywateli rzeczywiście uprawnionych do zabezpieczenia społecznego bez własnej winy znalazła się w legislacyjnej pułapce. Należy podkreślić, że zasada określoności pojmowana jako element konieczny zasady demokratycznego państwa prawnego została dookreślona i rozwinięta w orzecznictwie Trybunału Konstytucyjnego. Przyjmuje się, że norma konstytucyjna nakazująca zachowanie odpowiedniej określoności regulacji prawnych ma charakter zasady prawa.

Do katalogu obowiązków ustawodawcy zwykłego należy dążenie do „optymalizacji” zasad konstytucyjnych, to jest ich urzeczywistnienia w maksymalnym możliwym stopniu w procesie stanowienia prawa. Należy przy tym podkreślić, że wymóg określoności prawa dotyczy zarówno treści, jak i formy. Na oba wymiary określoności prawa składają się trzy kryteria: precyzyjności regulacji prawnej, jasności przepisu i „legislacyjnej poprawności”. Tworzą one tak zwany test określoności prawa, który powinien być odnoszony do analizowanej regulacji ${ }^{17}$.

Niespełnienie wymogów testu określoności przez kwestionowany przepis, a zwłaszcza niespełnienie wymogu legislacyjnej poprawności, skutkuje naruszeniem zasady równości podmiotów. Konstytucja RP w art. 32 ust. 1 przesądza, że wszyscy są równi wobec prawa i mają prawo do równego traktowania przez władze publiczne. Przewodnia dla postanowień rozdziału II Konstytucji $\mathrm{RP}^{18}$ zasada równości została dopełniona konstytucyjnym zakazem dyskryminacji, wedle którego nikt nie może być dyskryminowany w życiu politycznym, społecznym lub gospodarczym z jakiejkolwiek przyczyny (art. 32 ust. 2 Konstytucji RP). W piśmiennictwie nawet akcentuje się szczególność tego prawa jako tak zwane podmiotowe prawo do równego traktowania ${ }^{19}$, czyli szczególnie korzystnej sytuacji prawnej jednostki - uprawnienia pozwalającego obywatelowi (jednostce lub jednostkom) swobodnie wykonywać działania oraz skutecznie domagać się od innych podmiotów realizacji nałożonych na nich — przez normy prawne — obo-

15 Wyrok TK z 22 maja 2002 roku, K 6/02, OTK ZU 3A/2002, poz. 33.

16 Wyrok TK z 22 maja 2002 roku, K 6/02; wyrok TK z 20 listopada 2002 roku, K 41/02. Zob. też J. Zaleśny, Zasada prawidtowej legislacji, „Studia Politologiczne” 13, 2009, s. 15; zob. także S. Wronkowska, M. Zieliński, Komentarz do zasad techniki prawodawczej z dnia 20 czerwca 2002 r., Warszawa 2012, s. 7-8.

17 Por. wyrok TK z 28 października 2009 roku, Kp 3/09, OTK ZU 9A/2009, poz. 138.

18 Tytuł rozdziału II Konstytucji Rzeczypospolitej Polskiej: Wolności, prawa i obowiązi człowieka i obywatela.

19 Por. P. Tuleja, Stosowanie Konstytucji RP w świetle zasady jej nadrzędności. Wybrane problemy, Warszawa 2003, s. 123. 
wiązków ${ }^{20}$. Zasada równości obejmuje nakaz jednakowego traktowania wszystkich podmiotów wyróżnionych według cechy istotnej, to jest cechy prawnie relewantnej w danej sferze stosunków.

Dodajmy, że w komentowanym przypadku cechą istotną, spajającą grono uprawnionych do zabezpieczenia społecznego jest spełnienie faktycznych wymogów uzyskania tego świadczenia. Ograniczenie czy likwidacja dostępu do tego świadczenia jest następstwem nienależytego wywiązania się przez władzę publiczną z obowiązku stworzenia odpowiednich regulacji umożliwiających skorzystanie z zabezpieczenia społecznego przez wszystkich faktycznie do tego uprawnionych. Wystąpienie blokady dostępu do konstytucyjnie należnego obywatelowi zabezpieczenia społecznego stanowi konsekwencję przyjęcia „nieszczelnej” regulacji, a następnie skonstruowania wadliwie (nieefektywnie) działającego systemu.

4. Należy przypomnieć, że w odniesieniu do podejmowanej problematyki Trybunał Konstytucyjny wypowiedział się w wyroku z dnia 1 kwietnia 2008 roku ${ }^{21} \mathrm{~W}$ sprawie dotyczącej wysokości podstawy wymiaru emerytur. Trybunał Konstytucyjny po rozpoznaniu skargi konstytucyjnej H. Skrzyniarz orzekł o zgodności art. 15 ust. 1 ustawy z dnia 17 grudnia 1998 roku o emeryturach i rentach z Funduszu Ubezpieczeń Społecznych ${ }^{22}$ w zakresie, w jakim przepis ten ogranicza prawo wyboru 10 kolejnych lat do ostatnich 20 lat kalendarzowych poprzedzających bezpośrednio rok, w którym zgłoszono wniosek o emeryturę lub rentę, $\mathrm{z}$ art. 2, art. 32 ust. 1 i art. 67 ust. 1 Konstytucji RP. W szczególności w uzasadnieniu tego wyroku Trybunał podkreślił, że

w dalszym ciągu aktualność zachowuje pogląd, że także w sferze prawa do zabezpieczenia społecznego art. 32 ust. 1 Konstytucji jest źródłem zasady równości wobec prawa, rozumianej jako nakaz, aby wszystkie podmioty prawa (adresaci norm prawnych), charakteryzujące się daną cechą istotną (relewantną) w równym stopniu, były traktowane równo - bez dyskryminowania i faworyzowania.

W orzecznictwie Trybunału Konstytucyjnego dopuszcza się różnicowanie regulacji podmiotów podobnych w razie spełnienia następujących warunków:

- musi ono mieć charakter relewantny (pozostawać w bezpośrednim związku z celem i zasadniczą treścią przepisów, w których zawarta jest kontrolowana norma, oraz służyć realizacji tego celu i treści; wprowadzone zróżnicowania muszą być racjonalnie uzasadnione);

— musi mieć charakter proporcjonalny (waga interesu, któremu ma służyć różnicowanie sytuacji adresatów normy, musi pozostawać w odpowiedniej pro-

20 Por. B. Banaszak, Prawo konstytucyjne, Warszawa 2015, s. 369 i przywoływaną tam literaturę. Por. też T. Chauvin, T. Stawecki, P. Winczorek, Wstep do prawoznawstwa, Warszawa 2016, s. $107-108$.

21 Sygn. akt SK 96/06, OTK ZU 3A/2008, poz. 40.

22 Dz.U. z 2004 r. Nr 39, poz. 353 ze zm. 
porcji do wagi interesów, które zostaną naruszone w wyniku nierównego potraktowania podmiotów podobnych);

— musi pozostawać w związku z zasadami, wartościami i normami konstytucyjnymi uzasadniającymi odmienne traktowanie podmiotów podobnych ${ }^{23}$.

W przywoływanym już rozstrzygnięciu w sprawie SK 96/06 Trybunał Konstytucyjny podtrzymał stanowisko, że

zgodny z założeniami konstytucyjnymi system ubezpieczeń społecznych nie może być oparty na zasadzie „absolutnej” równości, a przede wszystkim na jednolitych dla wszystkich ubezpieczonych wymaganiach dotyczących wieku emerytalnego i długości zatrudnienia ${ }^{24}$,

\section{natomiast}

zasada sprawiedliwości społecznej na gruncie ubezpieczeń społecznych uzasadnia takie zróżnicowanie prawa do emerytur i rent, które wynika z wkładu pracy mierzonego wysokością wynagrodzenia i związanej z tą wysokością składki na ubezpieczenia społeczne oraz długością okresu zatrudnienia, z korektą na rzecz uwzględnienia redystrybucyjnej funkcji ubezpieczeń społecznych ${ }^{25}$.

Taka sytuacja nie zachodzi w omawianym przypadku, w którym przyczyną nieuzasadnionego różnicowania sytuacji prawnej obywateli jest niezapewnienie przez państwo możliwości swobodnego dotarcia do dotyczącej ich dokumentacji osobowej i płacowej. Innymi słowy, nie ma żadnego uzasadnienia dla różnicowania mającego źródło w $\S 28$ ust. 1 rozporządzenia MPiPS w sprawie postępowania o świadczenia emerytalno-rentowe.

Należy podzielić pogląd Trybunału Konstytucyjnego, że odstępstwa od zasady równości są dopuszczalne, o ile są odpowiednio uzasadnione ${ }^{26}$, co w badanym przypadku nie występuje. Przeciwnie, cechą relewantną łączącą przez ich upodobnienie do siebie podmioty uprawnione do zabezpieczenia społecznego jest spełnienie rzeczywistych (faktycznych) przesłanek uzyskania prawa do niego. I nie mogą stać temu na przeszkodzie okoliczności formalne, zawinione przez organy władzy publicznej, w pierwszej kolejności organy prawodawcze, a w następnej — właściwe organy władzy publicznej wykonujące nakazy prawa. Tylko takie rozumowanie może zostać uznane za sprawiedliwe społecznie.

23 Por. np. wyrok TK z 16 grudnia 1997 roku, K 8/97, OTK ZU nr 5-6/1997, poz. 70; wyrok TK z 24 lutego 1999 roku, SK 4/98, OTK ZU nr 2/1999, poz. 24; wyrok TK z 28 maja 2002 roku, P 10/01, OTK ZU 3A/2002, poz. 35; wyrok TK z 21 lutego 2006 roku, K 1/05, OTK ZU nr 2/A/2006, poz. 18.

24 Wyrok TK z 8 września 2005 roku, P 17/04, OTK ZU 8A/2005, poz. 90.

25 Wyrok TK z 24 października 2005 roku, P 13/04, OTK ZU 9A/2005, poz. 102.

26 A. Łabno, A. Bisztyga, Konstytucyjne aspekty ustalania wieku emerytalnego górników. Ekspertyza prawna w sprawie projektu ustawy o zmianie ustawy z dnia 17 grudnia 1988 roku o emeryturach i rentach z Funduszu Ubezpieczeń Społecznych sporzadzona dla Niezależnego Samorzadnego Związu Zawodowego „, Solidarność Górników”, „Zeszyty Naukowe Górnośląskiej Wyższej Szkoły Handlowej im. Wojciecha Korfantego", z. 32. Zeszyt Naukowy Katedry Prawa i Administracji, red. A. Bisztyga, Katowice 2007, s. 125. 
A contrario, rozumowanie różnicujące grupę uprawnionych do zabezpieczenia społecznego ze względu na wtórne wobec faktycznych i przez to drugorzędne okoliczności formalne musiałoby rodzić poczucie społecznej niesprawiedliwości. Aspekt sprawiedliwości społecznej jest w omawianym przypadku poważnie pogłębiany, zważywszy, że problem dotyczy w znacznej mierze obywateli w starszym wieku oraz borykających się ze związanymi z tym problemami zdrowotnymi, a zatem mających prawo oczekiwać, że władza publiczna zapewni prawidłową realizację przyznanych im uprawnień oraz zagwarantuje ich jednakowe traktowanie niezależnie od tego, u jakich pracodawców świadczyli pracę.

5. Przenosząc te rozważania na grunt analizowanej regulacji (§ 28 ust. 1 rozporządzenia MPiPS w sprawie postępowania o świadczenia emerytalno-rentowe), należy stwierdzić, że w przepisie tym nie zostały spełnione warunki dające podstawę do odstępstwa od zasady równości. Nie znajduje bowiem żadnego uzasadnienia to, że w mniej korzystnej sytuacji znajdują się pracownicy zlikwidowanych zakładów pracy, zwłaszcza małych niepublicznych podmiotów, którzy mają trudności w ustaleniu miejsca przechowywania dokumentacji, w przeciwieństwie do pracowników podmiotów istniejących, a także nieistniejących już podmiotów o charakterze publicznym, w przypadku których uzyskanie kopii dokumentów, nawet w razie likwidacji lub przekształcenia tych podmiotów, nie stwarza problemów.

O tym, jak poważny i społecznie dokuczliwy jest to problem, świadczą argumenty wynikające $\mathrm{z}$ uzasadnienia poselskiego projektu ustawy o zmianie ustawy o emeryturach i rentach z Funduszu Ubezpieczeń Społecznych ${ }^{27}$. Projekt zakłada nowelizację ustawy o emeryturach i rentach z Funduszu Ubezpieczeń Społecznych w zakresie obliczania podstawy wymiaru świadczeń w ten sposób,

aby przy obliczaniu podstawy wymiaru składki na ubezpieczenie społeczne za okres pracy, za który nie można przedłożyć odpowiednich dokumentów świadczących o wysokości wynagrodzenia, podstawę stanowiła kwota obowiązującego w tym okresie najniższego wynagrodzenia za pracę, proporcjonalnie do wymiaru czasu pracy.

Z uzasadnienia jednoznacznie wynika, że ustawodawca ma świadomość, że

wielu ubezpieczonych nie jest w stanie przedłożyć brakującej dokumentacji i z tego tytułu są pozbawieni możliwości uzyskania wyższego świadczenia. Brak dokumentacji płacowej umożliwiającej ustalenie lub przeliczenie wysokości emerytury lub renty zgodnie z obowiązującymi od dnia 1 stycznia 1999 r. nowymi zasadami jest zmorą dużej grupy emerytów. Powoduje często przyjmowanie tzw. miejsc zerowych przy ustalaniu podstawy emerytury lub renty w zależności od roku przyznania świadczenia na podstawie poprzednio obowiązujących przepisów, wybranych z ostatnich 20 lat kalendarzowych poprzedzających rok zgłoszenia wniosku o przyznanie świadczenia. Uniemożliwia to również skorzystanie przez osoby pobierające świadczenia (z już wybranych lat) z możliwości wskazania podstawy emerytury lub renty z innych okresów ubezpieczenia z 20 lat

27 Druk nr 633, kadencja VI; zob. też opinie prawne do poselskiego projektu ustawy o zmianie ustawy o emeryturach i rentach z Funduszu Ubezpieczeń Społecznych (druk nr 633) autorstwa J.M. Karolczak i B. Kłos, http://orka.sejm.gov.pl/rexdomk6.nsf/Opdodr?OpenPage\&nr=633 (dostęp: 1.09.2017). 
kalendarzowych poprzedzających rok zgłoszenia wniosku o przyznanie świadczenia, wybranych z całego okresu ubezpieczenia.

Ponadto w uzasadnieniu tego projektu ustawodawca potwierdza, że obywatele pomimo dołożenia wszelkich starań nie są w stanie przedłożyć brakującej dokumentacji i z tego tytułu są pozbawieni możliwości uzyskania wyższego świadczenia, a ciężar dowodu wysokości uzyskiwanych zarobków obciąża wyłącznie ubezpieczonych, natomiast brak dokumentacji płacowej z niektórych lat okresu ubezpieczenia uniemożliwia organowi rentowemu podjęcie decyzji $\mathrm{w}$ sprawie ustalenia podstawy wymiaru emerytury lub renty nawet wtedy, gdy udowodniony okres zatrudnienia miał miejsce $\mathrm{w}$ dawnym uspołecznionym zakładzie pracy i dotyczył pełnego etatu.

Z uzasadnienia tego projektu wynika również, że Ministerstwo Pracy i Polityki Społecznej, mając świadomość brakującej dokumentacji, przyjęło wspólnie z Zakładem Ubezpieczeń Społecznych w lipcu 1999 roku następujące wspólne stanowisko w sprawie dokumentacji płacowej.

Po pierwsze, podstawowym dokumentem potwierdzającym wysokość wynagrodzenia $\mathrm{w}$ celu ustalenia podstawy wymiaru emerytury lub renty oraz na potrzeby ustalenia kapitału początkowego jest zaświadczenie wystawione przez pracodawcę na druku Zakładu Ubezpieczeń Społecznych Rp 7 lub legitymacja ubezpieczeniowa zawierająca wpisy o okresach zatrudnienia i osiąganym w danym okresie wynagrodzeniu.

Po drugie, ustalenia podstawy wymiaru świadczenia można dokonać również na podstawie legitymacji ubezpieczeniowej zawierającej odpowiednie wpisy o okresach zatrudnienia i osiąganych w tych okresach wynagrodzeniach.

Po trzecie, w razie braku w zakładzie pracy dokumentacji płacowej oraz braku wpisu o zarobkach w legitymacji ubezpieczeniowej dopuszcza się wystawianie zaświadczenia o zarobkach na druku ZUS Rp 7 na podstawie dokumentacji zastępczej, to jest na podstawie akt osobowych pracownika, a więc na podstawie umów o pracę, pism o powołaniu, mianowaniu oraz innych pism określających wynagrodzenie pracownika, których okres przechowywania wynosi 50 lat od zakończenia pracy przez pracownika.

Po czwarte, dopuszcza się ustalanie przez zakład pracy wynagrodzenia określonego w dokumentacji osobowej stawką godzinową pod warunkiem, że w aktach osobowych pracownika zachowały się dane dotyczące liczby fizycznie przepracowanych godzin w danym okresie (dziennie, tygodniowo, miesięcznie).

Wskazane argumenty ilustrują nieefektywność systemu przechowywania dokumentacji płacowej i osobowej, co w konsekwencji prowadziło do naruszenia postanowień Konstytucji RP. Wychodząc naprzeciw, przyjęto ustawę z dnia 4 września 2008 roku o zmianie ustawy o emeryturach i rentach z Funduszu Ubezpieczeń Społecznych, stanowiącą między innymi, że jeżeli nie można ustalić podstawy wymiaru składek w okresie pozostawania w stosunku pracy wskazanym 
do ustalenia podstawy wymiaru emerytury i renty, za podstawę wymiaru składek przyjmuje się kwotę obowiązującego w tym okresie minimalnego wynagrodzenia pracowników, proporcjonalnie do okresu podlegania ubezpieczeniu i wymiaru czasu pracy (ust. 2a), jak również że przepisy ust. 2a stosuje się odpowiednio do osób uznanych za repatriantów (ust. 2b).

Rozwiązanie to w pewnym zakresie ułatwiło osobom dochodzenie praw emerytalnych lub rentowych, ale nie rozwiązało całkowicie problemu. Niezależnie zatem od tych rozwiązań należy stwierdzić, że aktualnie funkcjonujący system przechowywania dokumentacji płacowej i osobowej nie urzeczywistnia postanowień Konstytucji RP, co dotyczy zwłaszcza $\S 28$ ust. 1 rozporządzenia MPiPS w sprawie postępowania o świadczenia emerytalno-rentowe będącego elementem tego systemu, albowiem dopuszcza on możliwość interpretacji tego przepisu w sposób niezgodny w szczególności z konstytucyjną zasadą równości (art. 32 ust. 1) oraz z konstytucyjnym prawem do zabezpieczenia społecznego (art. 67 ust. 1). Prowadzi on do pogorszenia sytuacji pracowników zlikwidowanych zakładów pracy, zwłaszcza małych niepublicznych podmiotów, w przeciwieństwie do pracowników podmiotów istniejących, a także nieistniejących już podmiotów o charakterze publicznym, w przypadku których uzyskanie kopii dokumentów, nawet w razie likwidacji lub przekształcenia tych podmiotów, nie stwarza problemów.

Dał temu wyraz Trybunał Konstytucyjny w przywoływanym już uzasadnieniu wyroku w sprawie SK 96/06, odnosząc się do zarzutu naruszenia zasady lojalności państwa względem obywateli przez art. 15 ust. 1 ustawy emerytalnej ze względu na jego nieskorelowanie z przepisami dotyczącymi zasad przechowywania dokumentacji płacowej. Trybunał Konstytucyjny wskazał, że nie może polemizować z tym, że w okresie PRL nie było obowiązku gromadzenia tego typu danych za cały czas aktywności zawodowej, co mogło powodować jej niszczenie po upływie określonego czasu. Trybunał dostrzegł, iż nie ulega wątpliwości, że „krótkowzroczność” ustawodawcy przy ustalaniu zasad archiwizacji tych danych może utrudniać udokumentowanie przez zainteresowanych ich dochodów do celów emerytalnych. Ewentualne zarzuty z tego powodu nie powinny jednak być łączone z zaskarżonym przepisem, gdyż określa on jedynie okres, który jest brany pod uwagę przy obliczaniu wymiaru świadczenia.

6. Zgodnie z art. 67 ust. 1 obywatel ma prawo do zabezpieczenia społecznego w razie niezdolności do pracy ze względu na chorobę lub inwalidztwo oraz po osiągnięciu wieku emerytalnego, a zakres i formy zabezpieczenia społecznego określa ustawa. Na gruncie Konstytucji RP prawo do zabezpieczenia społecznego ma wyłącznie obywatelski charakter ${ }^{28}$. To konstytucyjne prawo obejmuje całokształt świadczeń, jakie ze środków publicznych są przyznawane obywatelowi

28 A. Bisztyga, B. Przywora, Prawa socjalne i ich ochrona $w$ świetle Konstytucji Rzeczypospolitej Polskiej, [w:] Ochrona praw człowieka. Zagadnienia praktyczne, red. A. Hauser, M. Urbaniak, Poznań 2019, s. 23. 
znajdującemu się w potrzebie ${ }^{29}$, niemniej nie odnotowujemy tu zróżnicowania podstawowych technik realizacji tego zabezpieczenia, w szczególności nie dokonano wyróżnienia ubezpieczenia społecznego, zaopatrzenia społecznego i pomocy społecznej ${ }^{30}$.

Samo pojęcie zabezpieczenia społecznego pojawiło się w języku prawnym wraz z wejściem w życie obowiązującej Konstytucji RP ${ }^{31}$. Prawo do zabezpieczenia społecznego należy do tak zwanych praw podmiotowych, a jego rangę dodatkowo podkreślono przez nadanie mu w pełni egzekwowalnego charakteru. Prawo to nie stanowi zatem jedynie programowej normy ${ }^{32}$. Zagwarantowanie tego prawa nie jest przejawem dobrej woli państwa, lecz jego obowiązkiem.

Prawo to nie zostało ujęte w kategorii prawa człowieka, lecz jako prawo obywatelskie, jako że jego podmiotem jest obywatel. Zważywszy na charakter zagadnienia, chodzi tu głównie - acz nie wyłącznie — o obywatela polskiego. Regulacja ta dotyczy także obywateli innych państw będących sygnatariuszami określonej umowy międzynarodowej. Przesądzające jest w tym wypadku kryterium istnienia więzi prawnej między obywatelem a konkretnym państwem należącym wraz z Rzeczpospolitą Polską do określonej organizacji międzynarodowej $^{33}$. W dalszej części opracowania będą jednak akcentowane kwestie dotyczące polskiego obywatelstwa osób ze względu na ich liczebną dominację w badanej sprawie, ogromną skalę problemu i skutków finansowych zwłaszcza po stronie obywateli polskich oraz ze względu na związki przyjętej argumentacji z ideą dobra wspólnego, jakim jest Rzeczpospolita Polska (art. 1 Konstytucji RP).

Szczególnie istotne i dodatkowo konstytuujące znaczenie tego prawa jest to, że ograniczenie zakresu dochodzenia praw socjalnych na poziomie ustawowym określone w art. 81 Konstytucji RP nie odnosi się do zabezpieczenia społecznego $^{34}$. Zostało to potwierdzone w orzecznictwie Trybunału Konstytucyjnego ${ }^{35}$. Należy podkreślić, że treścią tego prawa jest zapewnienie każdemu obywatelowi świadczeń na wypadek: niezdolności do pracy ze względu na chorobę, niezdolno-

29 Wyrok TK z 20 września 2001 roku, K 15/01, OTK ZU 8/2001, poz. 252; zob. też L. Garlicki, Komentarz do artykułu 67, [w:] Konstytucja Rzeczypospolitej Polskiej. Komentarz, t. 3, red. L. Garlicki, Warszawa 2016, s. 3.

30 K. Kolasiński, Prawo pracy i zabezpieczenia społecznego, Toruń 2001, s. 112-113.

31 M. Zieleniecki, Prawo do zabezpieczenia społecznego, „Gdańskie Studia Prawnicze” 13, 2005, s. 579.

32 Por. R. Babińska-Górecka, Skutki prawne orzeczeń Trybunału Konstytucyjnego w dziedzinie ubezpieczenia społecznego, Warszawa 2014, s. 229.

33 M. Jabłoński, Zasada różnicowania zakresu realizacji konstytucyjnych wolności i praw jednostki w oparciu o kryterium obywatelstwa polskiego, [w:] Wolności i prawa jednostki w Konstytucji $R P$, t. 1. Idee i zasady przewodnie konstytucyjnej regulacji wolności i praw jednostki $w R P$, red. M. Jabłoński, Warszawa 2010, s. 539.

34 A. Bisztyga, Regulation of social rights in the Constitution of the Republic of Poland, „Annales Universitatis Apulensis, Series Jurisprudentia” 18, 2015, s. 130; zob. też M. Granat, Prawo konstytucyjne. Pytania i odpowiedzi, Warszawa 2019, s. 149.

35 Wyrok TK z 8 maja 2000 roku, SK 22/99. 
ści do pracy ze względu na inwalidztwo, osiągnięcia wieku emerytalnego, pozostawania bez pracy nie z własnej woli i nieposiadania innych środków utrzymania.

Norma zawarta w art. 67 ust. 1 Konstytucji RP jest adresowana do władz publicznych RP. Działa ona wybitnie wertykalnie, a nie horyzontalnie. Wynika z niej prawo każdego polskiego obywatela do zagwarantowania i do realizacji zabezpieczenia społecznego przez państwo. Natomiast po stronie władz publicznych odpowiednikiem tego prawa jest obowiązek stworzenia prawnej infrastruktury dla systemu zabezpieczenia społecznego ${ }^{36}$, respektującej konstytucyjną zasadę równości. Na prawodawcy ciąży konstytucyjny obowiązek konkretyzowania uprawnień obywateli, w tym obowiązek konkretyzowania postanowień art. 67 ust. 1 Konstytucji RP przez stworzenie odpowiedniej ,prawnej infrastruktury”, za sprawą której skutecznie, bez naruszenia powszechności prawa do zabezpieczenia społecznego oraz prawa do równego traktowania, byłoby realizowane konstytucyjne prawo do zabezpieczenia społecznego. Konstytucyjne prawo polskiego obywatela do społecznego zabezpieczenia nie może być w procesie jego konkretyzacji redagowane, a następnie wykładane w sposób zawężający to prawo, zarówno przedmiotowo, jak i podmiotowo, jako że służy ono każdemu polskiemu obywatelowi. Na prawodawcy ciąży konstytucyjny obowiązek budowy i dbania o poprawność funkcjonowania „prawnej infrastruktury” systemu zabezpieczenia społecznego, bez rozwiązań dyskryminujących i faworyzujących w ramach korpusu obywateli, którzy rzeczywiście wypracowali sobie prawo do zabezpieczenia społecznego w określonym wymiarze. Obowiązujące prawo (a uwaga ta dotyczy kwestionowanego $\S 28$ rozporządzenia MPiPS w sprawie postępowania o świadczenia emerytalno-rentowe) nie może rodzić skutku dyskryminującego czy upośledzającego sytuację prawną grupy polskich obywateli w drodze stworzenia wymogów, których przedstawiciele tej grupy nie mogą spełnić i to pomimo dotrzymania przez nich należytej staranności w swym działaniu na rzecz dotarcia do ich dokumentacji osobowej i płacowej w celu należytego udokumentowania okresów świadczenia przez siebie pracy, a zatem bez ich winy.

W ocenie autora opracowania $\S 28$ rozporządzenia MPiPS w sprawie postępowania o świadczenia emerytalno-rentowe w obowiązującym kształcie ,przerzuca" na obywateli powinności, z których powinny wywiązać się władze publiczne państwa, które powinno zadbać o efektywność systemu przechowywania dokumentacji osobowej i płacowej pracodawców. W efekcie po stronie tych obywateli rodzi się zrozumiałe rozczarowanie instytucją państwa, poczucie wyrządzonej przez nie krzywdy spowodowanej niedostateczną dbałością o zagwarantowanie przez nie obowiązku państwa wyrażonego w art. 67 ust. 1 Konstytucji RP. Reakcji w tej sprawie „domaga się także potrzeba” respektowania zasady solidaryzmu

36 Konstytucja RP co prawda nie posługuje się pojęciem systemu zabezpieczenia społecznego, ale bez jego budowy i istnienia realizacja dyspozycji normy zawartej w artykule 67 Konstytucji RP nie byłaby możliwa. 
społecznego wyrażona w art. 20 Konstytucji RP. Zasada ta stanowi jedno z kryteriów projektowania i wprowadzania świadczeń emerytalnych i oznacza konieczność postrzegania przyjętego modelu tych świadczeń w perspektywie wszystkich, a nie części osób osiągających wiek emerytalny ${ }^{37}$.

Przyczyny tego stanu rzeczy są zapewne niezamierzone, są jednak niezrozumiałe i tkwią w legislacyjnej niedbałości wyrażonej w redakcji § 28 rozporządzenia MPiPS w sprawie postępowania o świadczenia emerytalno-rentowe. Jest to sytuacja, którą można klasyfikować jako nielojalność państwa wobec własnych obywateli, co zarówno w teorii, jak i w praktyce stanowi podważenie idei dobra wspólnego oraz skutkuje naruszeniem zasady zaufania obywateli do państwa i jego instytucji, co jest bardzo poważnym zarzutem. Przeciwko $§ 28$ rozporządzenia MPiPS w sprawie postępowania o świadczenia emerytalno-rentowe w jego dotychczasowym brzmieniu przemawia jego powszechnie niekorzystna, praktyczna wykładnia naruszająca konstytucyjną zasadę równości oraz powszechność konstytucyjnego prawa obywatela wyrażonego w art. 67 Konstytucji RP.

Zawarty w $\S 28$ rozporządzenia MPiPS w sprawie postępowania o świadczenia emerytalno-rentowe przepis po prostu dzieli swoich adresatów. Nie do przyjęcia jest stosowanie tego przepisu w sposób rodzący praktykę dyskryminującą część jego adresatów i to - dodajmy — zasadniczo część społecznie słabszą. $\mathrm{Z}$ tego fragmentu rozważań szczególnie mocno wypływa potrzeba uzdrowienia stanu prawnej dyskryminacji. Istniejącą sytuację prawną, w jakiej z powodu obowiązywania wadliwie skonstruowanego przepisu znaleźli się liczni polscy obywatele, nie sposób uznać za sprawiedliwą społecznie (art. 2 Konstytucji RP). Uwaga dotycząca kierunku potencjalnej modyfikacji § 28 zostanie wyrażona w końcowej części artykułu.

Nie jest pożądane i właściwe, aby redakcja przepisu, jego interpretacja i w konsekwencji oparta na nim praktyka systemu zabezpieczenia społecznego prowadziły do dzielenia obywateli na lepszych — beneficjentów, wobec których system działa poprawnie, oraz na gorszych, wobec których system jest wadliwy i którzy w związku z tym mają prawo czuć się pokrzywdzeni ze względu na naruszenie ich konstytucyjnych praw (art. 32 ust. 1, art. 67 ust. $1 \mathrm{w} \mathrm{zw.} \mathrm{z} \mathrm{art.} \mathrm{2,} \mathrm{art.} 1$ i art. 20 Konstytucji RP).

Artykuł 67 ustawy zasadniczej ma charakter odsyłający, albowiem ustrojodawca scedował na ustawodawcę zwykłego obowiązek kształtowania zakresu i form, w których ma być urzeczywistniane to prawo. Ustawodawca, tworząc system zabezpieczenia społecznego, powinien każdorazowo uwzględniać wiele zmiennych czynników, jak sytuacja gospodarcza, przewidywane trendy gospodarcze i społeczne, demograficzne, liczba osób pracujących w stosunku do liczby

37 Wyrok TK z 4 listopada 2015 roku, K 1/14, OTK ZU 10A/2015, poz. 163. 
świadczeniobiorców opłacających składki ${ }^{38}$. Należy przy tym podkreślić, że swoboda ustawodawcy w kształtowaniu tego prawa nie jest nieograniczona. Ustawodawca ma obowiązek uwzględnienia także innych wartości, takich jak godność człowieka, ochrona praw nabytych, określoność prawa, równość wobec prawa oraz stan finansów publicznych ${ }^{39}$, a także istniejące potrzeby społeczne. Jednocześnie ustawodawca musi brać pod uwagę realne możliwości zaspokojenia tych potrze $^{40}$ oraz konieczność zachowania równowagi budżetowej.

Przypomnijmy, że obowiązujący $\S 28$ ust. 1 rozporządzenia MPiPS w sprawie postępowania o świadczenia emerytalno-rentowe dopuszcza możliwość interpretacji tego przepisu w sposób niezgodny w szczególności z zasadą równości (art. 32 ust. 1) oraz z prawem do zabezpieczenia społecznego (art. 67 ust. 1), prowadząc do pogorszenia sytuacji pracowników zlikwidowanych zakładów pracy, zwłaszcza małych niepublicznych podmiotów, w przeciwieństwie do pracowników podmiotów istniejących, a także nieistniejących już podmiotów o charakterze publicznym, w przypadku których uzyskanie kopii dokumentów, nawet w razie likwidacji lub przekształcenia tych podmiotów, nie stwarza problemów.

Zarówno komentowany $\S 28$ rozporządzenia MPiPS w sprawie postępowania o świadczenia emerytalno-rentowe, jak i rozdziały 4 a i 4 b ustawy o narodowym zasobie archiwalnym oraz o archiwach z 1983 roku regulują szczegółowe kwestie techniczne. Regulacje zawarte w tych rozdziałach stanowią o działalności gospodarczej w zakresie przechowywania dokumentacji osobowej i płacowej pracodawców o czasowym okresie przechowywania oraz postępowania $\mathrm{z}$ dokumentacją osobową i płacową w przypadku likwidacji lub upadłości pracodawcy. Oceniając całościowo ich obowiązywanie, należy stwierdzić istnienie utrudnień w realizacji pełni konstytucyjnego prawa do zabezpieczenia społecznego. Główna przyczyna tkwi jednak w $\S 28$ rozporządzenia MPiPS w sprawie postępowania o świadczenia emerytalno-rentowe. Wymagana jest zatem względnie dynamiczna, prawodawcza korekta, która pozwoliłaby na możliwie szybkie „odblokowanie stanu swoistej niemocy" niosącego nieuzasadnioną krzywdę i straty po stronie znacznej części korpusu rzeczywiście uprawnionych do świadczenia z tytułu społecznego zabezpieczenia. Podkreślmy, że obywatele są pokrzywdzeni stosowaniem $\S 28$ rozporządzenia MPiPS w sprawie postępowania o świadczenia emerytalno-rentowe i w konsekwencji opartą na nim praktyką. W rzeczywistości nabyli prawo do zabezpieczenia społecznego, natomiast $z$ winy prawodawcy i innych władz publicznych mają problem $\mathrm{z}$ udokumentowaniem przesłanek formalnego stwierdzenia jego nabycia.

38 Zob. wyrok pełnego składu TK z 19 grudnia 2012 roku, K 9/12, OTK ZU 11A/2012, poz. 136.

39 Zob. wyrok pełnego składu TK z 4 listopada 2015 roku, K 1/14, OTK ZU 10A/2015, poz. 163.

40 Zob. ibidem; wyrok TK z 29 maja 2012 roku, SK 17/09, OTK ZU nr 5/A/2012, poz. 53. 
7. Warto w tym punkcie wskazać wnioski z sygnalizowanej już kontroli Najwyższej Izby Kontroli. Celem kontroli NIK była ocena,

czy stworzony z Polsce system przechowywania dokumentacji osobowej i płacowej pracodawców umożliwił obywatelom realizację uprawnień do świadczeń emerytalnych za pracę przed $1999 \mathrm{r}$. w nieistniejących już zakładach pracy. Pytanie o sprawność funkcjonowania państwa w ww. zakresie nabiera szczególnego znaczenia w kontekście bezpośredniego wpływu wysokości ustalonego kapitału początkowego na wysokość emerytur, a więc na czynnik decydujący o jakości życia przechodzących na emeryturę obywateli ${ }^{41}$.

Zakresem kontroli objęto okres od 1 stycznia 2013 do 30 czerwca 2016 roku oraz działania wcześniejsze i późniejsze mające związek z działaniami podjętymi w wymienionym okresie. Kontrolę przeprowadzono w:

— Naczelnej Dyrekcji Archiwów Państwowych w Warszawie;

— pięciu archiwach państwowych (Archiwum Państwowym w Białymstoku, Archiwum Państwowym w Gdańsku, Archiwum Państwowym w Kielcach, Archiwum Narodowym w Krakowie i Archiwum Państwowym w Warszawie);

— pięciu Urzędach Marszałkowskich (Województwa Podlaskiego w Białymstoku, Województwa Pomorskiego w Gdańsku, Województwa Świętokrzyskiego w Kielcach, Województwa Małopolskiego w Krakowie i Województwa Mazowieckiego w Warszawie);

— pięciu Oddziałach ZUS (w Białymstoku, Gdańsku, Kielcach i Krakowie oraz w I Oddziale ZUS w Warszawie) $)^{42}$.

W ocenie Najwyższej Izby Kontroli

obecnie funkcjonujący w Polsce system przechowywania dokumentacji osobowej i płacowej pracodawców jest nieskuteczny i nie zapewnia wszystkim obywatelom możliwości dotarcia do dotyczącej ich dokumentacji osobowej i płacowej z okresu przed 1999 r., a tym samym możliwości pełnej realizacji uprawnień do świadczeń emerytalno-rentowych za pracę $\mathrm{w}$ tym okresie w nieistniejących już zakładach pracy ${ }^{43}$.

\section{Przykładowo z analiz Najwyższej Izby Kontroli wynika, że}

Przyszli emeryci i renciści nie mogą liczyć na skuteczną pomoc państwa w sytuacji, gdy przechowawca - nawet ten działający w majestacie prawa — odmawia lub zwleka $\mathrm{z}$ wydaniem dokumentów potrzebnych do naliczenia świadczeń emerytalno-rentowych, czy domaga się poniesienia przez zainteresowanego nieuzasadnionych opłat. Marszałkowie województw mają wprawdzie prawny obowiązek kontrolowania działalności przechowawców zarejestrowanych, jednak nawet w ich przypadku ustawodawca ograniczył uprawnienia kontrolne do niektórych zagadnień (weryfikacja danych ujętych w rejestrze, posiadanie odpowiedniej bazy organizacyjno-technicznej i regulaminu usług oraz zatrudnianie do obsługi dokumentacji osób posiadających specjalistyczne

${ }^{41}$ Informacja Najwyższej Izby Kontroli o wynikach kontroli: Skuteczność działania systemu przechowywania dokumentacji osobowej i płacowej, Warszawa, wrzesień 2017, LGD.410.018.2016, nr ewid.118/2017/P/16/064/LGD, s. 5, https://www.nik.gov.pl/plik/id,15248,vp,17729.pdf (dostęp: 9.11.2019).

42 Ibidem, s. 6.

43 Ibidem, s. 7. 
wykształcenie i praktykę zawodową). Należy przy tym podkreślić, że Marszałkowie Województw mieli problemy w zakresie wywiązywania się nawet $\mathrm{z}$ tak ograniczonych zadań kontrolnych wobec przechowawców zarejestrowanych ${ }^{44}$.

Najwyższa Izba Kontroli zwraca również uwagę na skalę problemu dotyczącego przechowywania dokumentów, mianowicie:

Według szacunków na dzień 1 stycznia 1999 r. liczba ubezpieczonych, którym ZUS powinien naliczyć kapitał początkowy, wynosiła około $11 \mathrm{mln}$. Tymczasem, według szacunkowych danych, na koniec 2016 r. (po 17 latach obowiązywania reformy) ZUS rozpatrzył sprawy o ustalenie kapitału początkowego dla około 8,8 mln ubezpieczonych, a jedynie w 2015 r. w ZUS zarejestrowano 1,4 mln spraw o naliczenie kapitału, w tym $0,2 \mathrm{mln}$ pierwszorazowych i 1,2 mln wymagających ponownego wydania decyzji ${ }^{45}$.

\section{Z przedstawionych przez NIK danych wynika, że}

w latach 1999-2015 przyznano po raz pierwszy około 4,5 mln świadczeń emerytalnorentowych, a same skutki finansowe wprowadzonej w 2009 r. zasady przyjmowania, w przypadku braku uznawanej dokumentacji dotyczącej wynagrodzenia, do podstawy wymiaru emerytur kwoty minimalnego wynagrodzenia zamiast dotychczasowej [stawki, tak zwanej stawki zerowej - A.B.] ZUS oszacował na $300 \mathrm{mln}$ zł rocznie ${ }^{46}$.

Wnioski Najwyższej Izby Kontroli ilustrują, jak istotne znaczenie ma konieczność skonstruowania rzetelnego systemu przechowywania dokumentacji osobowej i płacowej pracodawców, oraz pokazują uchybienia w dotychczasowym systemie. Najwyższa Izba Kontroli zwraca uwagę, że problem z przechowywaniem dokumentacji osobowej i płacowej pracodawców ma szerszy zasięg, nie dotyczy tylko dokumentacji sprzed 1999 roku, ale także późniejszej, a to

ze względu na obowiązujące zasady dokumentowania pracy w szczególnych warunkach lub w szczególnym charakterze, a w przypadku rent z uwagi na fakt, iż po $1998 \mathrm{r}$. przy ustalaniu prawa do renty i jej wysokości nadal bierze się pod uwagę okresy składkowe i nieskładkowe ${ }^{47}$.

W związku z tym ocena przechowywania dokumentacji osobowej i płacowej pracodawców musi być oceniona negatywnie. Obowiązujący system wymaga zmian, albowiem jest nieskuteczny — nie jest dla obywateli gwarancją dotarcia do dotyczącej ich dokumentacji osobowej oraz płacowej z okresu sprzed 1999 roku. W konsekwencji państwo nie zapewnia w pełni realizacji uprawnień do świadczeń emerytalno-rentowych za pracę $\mathrm{w}$ tym okresie $\mathrm{w}$ nieistniejących już zakładach pracy $^{48}$. Sytuacja ta domaga się pilnego uzdrowienia. Utrzymywanie w dalszym ciągu tego stanu rzeczy skutkuje stanem niezgodności z Konstytucją RP, a zwłaszcza z jej art. 32 ust. 1 i 67 ust. 1.

\footnotetext{
44 Ibidem, s. 10.

45 Ibidem, s. 11.

46 Ibidem.

47 Ibidem.

48 Ibidem, s. 7.
} 
8. Z przywoływanych już w preambule do Konstytucji RP postanowień wynika, że „działaniu instytucji publicznych należy zapewnić rzetelność i sprawność”. W odniesieniu do podjętego zagadnienia oznacza to obowiązek skonstruowania systemu przechowywania dokumentacji płacowej i osobowej, aby był rzetelny i sprawny w działaniu na rzecz obywateli. System ten powinien umożliwiać skuteczne dochodzenie przysługujących jednostce praw z tytułu zabezpieczenia społecznego.

W sprawozdaniu za 2018 rok Prezes NIK odniósł się do realizacji wniosków z kontroli Skuteczność dziatania systemu przechowywania dokumentacji osobowej i płacowej (P/16/064). Prezes NIK podkreślił, że wniosek

miał na celu zmiany w ustawie o narodowym zasobie archiwalnym i archiwach, aby wyeliminować jedną z przyczyn powstania zidentyfikowanych w wyniku kontroli nieprawidłowości o charakterze systemowym, poprzez wprowadzenie przepisów umożliwiających kontrolę przez wskazany organ wszystkich podmiotów przechowujących ww. dokumentację w ramach prowadzonej działalności gospodarczej (a nie tylko wpisanych do rejestru) oraz rozszerzenie uprawnień kontrolnych na realizację wszystkich obowiązków, ciążących na ww. podmiotach na podstawie tej ustawy oraz prawidłowość udostępniania przez nich przechowywanej dokumentacji (do tej pory kontrolę można było przeprowadzać jedynie w zakresie objętym wpisem do rejestru).

Odpowiedzią jest ustawa z dnia 10 stycznia 2018 roku o zmianie niektórych ustaw w związku ze skróceniem okresu przechowywania akt pracowniczych oraz ich elektronizacją ${ }^{49}$. W art. 2 pkt 1 zmieniono ustawę z dnia 14 lipca 1983

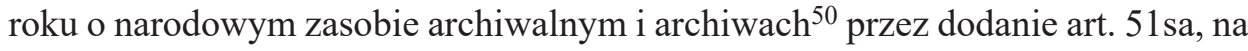
podstawie którego przyznano marszałkom województw uprawnienie do kontroli przedsiębiorcy, który wykonuje działalność gospodarczą w zakresie przechowywania dokumentacji bez uzyskania wpisu do rejestru. Z dniem 1 stycznia 2019 roku wskazana ustawa weszła w życie ${ }^{51}$.

W moim przekonaniu wyszczególnione zmiany, choć idą we właściwym kierunku, są niewystarczające. Z poczynionych ustaleń oraz przywołanych danych Najwyższej Izby Kontroli wynika, że skala i siła argumentów dowodzących wadliwości § 28 ust. 1 rozporządzenia MPiPS w sprawie postępowania o świadczenia emerytalno-rentowe skłaniają do rozważenia możliwości wzruszenia tego przepisu i następnie dokonania jego korekty utrzymanej w zgodności z art. 32 ust. 1, 67 ust. 1, a także art. 1, 2 i 20 Konstytucji RP.

Efekt ten można osiągnąć w dwojaki sposób - albo w drodze sformułowania przez podmioty legitymowane, o których mowa w art. 191 ust. 1 pkt 1 Konstytucji RP, wniosku do Trybunału Konstytucyjnego o zbadanie zgodności krytykowanego przepisu, albo przez wystąpienie do Ministra Rodziny, Pracy i Polityki Społecznej

49 Dz.U. poz. 357.

50 Dz.U. z 2018 r. poz. 217 ze zm.

51 Sprawozdanie z działalności Najwyższej Izby Kontroli w 2018 roku, s. 57, https://www.nik. gov.pl/plik/id,20101.pdf (dostęp: 9.11.2019). 
w celu rozważenia potrzeby zmiany brzmienia $\S 28$ ust. 1 rozporządzenia. Najwyższa Izba Kontroli proponuje

rozszerzenie określonego w $§ 28$ tego aktu prawnego katalogu środków dowodowych, które mogą potwierdzać wysokość wynagrodzenia, dochodu, przychodu oraz uposażenia przyjmowanego do ustalenia podstawy wymiaru świadczeń o dokumentację pochodzącą od nieuprawnionego przechowawcy (przepis powinien określać przesłanki, które powinny być spełnione, aby taka dokumentacja mogła być uwzględniona w procesie ustalania prawa i wysokości świadczeń emerytalnych $)^{52}$.

Biorąc jednak pod uwagę potrzebę możliwie szybkiego rozwiązania tego problemu oraz zważywszy na prorodzinne i prospołeczne nastawienie i aktualnie prowadzoną przez ministra politykę społeczną, za właściwszą ścieżkę działania i sanowania trwającej a niepożądanej sytuacji prawnej należy uznać nawiązanie w tej sprawie współpracy z Ministrem Rodziny, Pracy i Polityki Społecznej władnym dokonać odpowiedniej, prospołecznej i szybkiej — w porównaniu z procedurą trybunalską - korekty kwestionowanego przepisu.

Zasadne jest także wystąpienie do wszystkich instytucji szczebla centralnego oraz regionalnego o podjęcie szerokiej dyskusji dotyczącej zmian w systemie przechowywania dokumentacji, $\mathrm{w}$ tym zwłaszcza w rozporządzeniu MPiPS w sprawie postępowania o świadczenia emerytalno-rentowe oraz w ustawie o archiwach, w celu wyeliminowania przyczyn powstania zidentyfikowanych w wyniku kontroli nieprawidłowości o charakterze systemowym.

Nie wchodząc w rolę prawodawcy i nie sugerując nowej redakcji krytykowanego przepisu, można jednak wskazać kierunek postulowanych zmian. Otóż w obecnym brzmieniu przepis ten dopuszcza możliwość traktowania w charakterze środka dowodowego kopii wymienionych w nim dokumentów wydanych wyłącznie przez jednostki upoważnione do przechowywania dokumentacji zlikwidowanych lub przekształconych zakładów pracy. Zważywszy na skalę i charakter przedstawionego problemu, uzasadnione wydaje się rozszerzenie katalogu dopuszczonych przepisem środków dowodowych — pod ściśle i precyzyjnie określonymi warunkami - o dokumentację pochodzącą od przechowawców nieuprawnionych. Część dokumentacji osobowej i płacowej sprzed 1999 roku zapewne została już zniszczona, dlatego redukcja negatywnych skutków dotychczasowych zaniedbań może obecnie dotyczyć jedynie dokumentacji niezniszczonej, przechowywanej w większości przypadków przez przechowawców nieuprawnionych w rozumieniu $\S 28$ rozporządzenia MPiPS w sprawie postępowania o świadczenia emerytalno-rentowe. Stąd postulat wzbogacenia środków dowodowych właśnie o dokumentację pochodzącą od podmiotów nieuprawnionych. Dopełniająco można wskazać na potrzebę ustanowienia regulacji prawnej, na podstawie której archiwa państwowe mogłyby przejąć dokumentację od podmiotów, które weszły w jej posiadanie i przechowują ją bez tytułu prawnego.

52 Skuteczność działania systemu przechowywania dokumentacji..., s. 13. 
Należy też zaznaczyć, że sugerowana korekta nie dotyczy rozbudowy systemu zabezpieczenia społecznego, gdyż Konstytucja RP nie nakłada takiego obowiąz$\mathrm{ku}$. Istota korekty winna polegać na udrożnieniu tego systemu, fragmentarycznie zablokowanego na poziomie szczegółowych regulacji z krzywdą dla części jego uczestników.

\title{
THE ISSUE OF THE CONFORMITY OF THE REGULATIONS ON THE STORAGE SYSTEM OF PAYROLL RECORDS AND PERSONAL DATA TO THE CONSTITUTION OF THE REPUBLIC OF POLAND
}

\begin{abstract}
Summary
The aim of this work is to discuss the constitutionality of selected regulations on the system of the archaization and storage of payroll records and personal data. This issue has not only a theoretical, but also practical dimension. The study scrutinizes the guidelines from the report of the Supreme Audit Office. The Author postulates the amendments in the regulations.
\end{abstract}

Keywords: Constitution of the Republic of Poland of 2nd April 1997, payroll records and personal data of employees, the right to social security

\section{BIBLIOGRAFIA}

Babińska-Górecka R., Skutki prawne orzeczeń Trybunału Konstytucyjnego w dziedzinie ubezpieczenia społecznego, Warszawa 2014.

Banaszak B., Prawo konstytucyjne, Warszawa 2015.

Bielecki L. , Prawo do dobrej administracji jako wzmocnienie efektywności ochrony praw człowieka i obywatela w Unii Europejskiej, [w:] Europejski system ochrony praw człowieka. Aksjologia — instytucje - efektywnośćc, red. J. Jaskiernia, Torun 2015.

Bisztyga A., Opinia prawna nt. zgodności z Konstytucją Rzeczypospolitej Polskiej z dnia 2 kwietnia 1997 roku (Dz.U. z 1997r. Nr 78, poz. 483 z późń. zm.), w szczególności z jej artykułem 67 ust. 1 i artykutem 32 ust. 1, paragrafu 28 ust. 1 rozporzadzenia Ministra Pracy i Polityki Społecznej z dnia 11 października 2011 roku w sprawie postępowania o świadczenia emerytalno-rentowe (Dz.U. z 2011r. Nr 237, poz. 1412) w świetle rozdziatu $4 a$ i 4 b ustawy z dnia 14 lipca 1983 roku o narodowym zasobie archiwalnym i archiwach (Dz.U. z 2016 r. poz. 1506 z późn. $z m$.), sporządzona dla Departamentu Prawnego i Orzecznictwa Kontrolnego Najwyższej Izby Kontroli, Warszawa 2017.

Bisztyga A., Regulation of social rights in the Constitution of the Republic of Poland, „Annales Universitatis Apulensis. Series Jurisprudentia” 18, 2015.

Bisztyga A., Przywora B., Prawa socjalne i ich ochrona w świetle Konstytucji Rzeczypospolitej Polskiej, [w:] Ochrona praw człowieka. Zagadnienia praktyczne, red. A. Hauser, M. Urbaniak, Poznań 2019.

Chauvin T., Stawecki T., Winczorek P., Wstęp do prawoznawstwa, Warszawa 2016.

Garlicki L., Komentarz do artykutu 67, [w:] Konstytucja Rzeczypospolitej Polskiej. Komentarz, t. 3, red. L. Garlicki, Warszawa 2016. 
Granat M., Prawo konstytucyjne. Pytania i odpowiedzi, Warszawa 2019.

Jabłoński M., Zasada różnicowania zakresu realizacji konstytucyjnych wolności i praw jednostki w oparciu o kryterium obywatelstwa polskiego, [w:] Wolności i prawa jednostki w Konstytucji $R P$, t. 1. Idee i zasady przewodnie konstytucyjnej regulacji wolności i praw jednostki w RP, red. M. Jabłoński, Warszawa 2010.

Jackiewicz A., Prawo do dobrej administracji jako standard europejski, Torun 2008.

Kolasiński K., Prawo pracy i zabezpieczenia społecznego, Toruń 2001.

Kryszeń G., Państwo rzetelne i sprawne jako idea konstytucyjnego ustroju Rzeczypospolitej Polskiej, [w:] Zagadnienia prawa konstytucyjnego. Polskie i zagraniczne rozwiazania ustrojowe. Księga jubileuszowa dedykowana Profesorowi Dariuszowi Góreckiemu w siedemdziesiąta rocznicę urodzin, red. K. Skotnicki, K. Składkowski, A. Michalak, Łódź 2016.

Łabno A., Bisztyga A., Konstytucyjne aspekty ustalania wieku emerytalnego górników. Ekspertyza prawna w sprawie projektu ustawy o zmianie ustawy z dnia 17 grudnia 1988 roku o emeryturach i rentach z Funduszu Ubezpieczeń Społecznych sporzadzona dla Niezależnego Samorzadnego Związku Zawodowego „Solidarność Górników”, „Zeszyty Naukowe Górnośląskiej Wyższej Szkoły Handlowej im. Wojciecha Korfantego", z. 32. Zeszyt Naukowy Katedry Prawa i Administracji, red. A. Bisztyga, Katowice 2007.

Przywora B., Normatywny model przesądowej nieodpłatnej pomocy prawnej w Polsce, Warszawa 2019.

Tuleja P., Stosowanie Konstytucji RP w świetle zasady jej nadrzędności. Wybrane problemy, Warszawa 2003.

Wronkowska S., Zieliński M., Komentarz do zasad techniki prawodawczej z dnia 20 czerwca 2002 r. Warszawa 2012.

Zaleśny J., Zasada prawidłowej legislacji, „Studia Politologiczne” 13, 2009.

Zieleniecki M., Prawo do zabezpieczenia społecznego, „Gdańskie Studia Prawnicze” 13, 2005.

\section{ORZECZNICTWO}

\section{ORZECZNICTWO TRYBUNAŁU KONSTYTUCYJNEGO}

Wyrok pełnego składu TK z 19 grudnia 2012 roku, K 9/12, OTK ZU 11A/2012, poz. 136. Wyrok pełnego składu TK z 4 listopada 2015 roku, K 1/14, OTK ZU 10A/2015, poz. 163. Wyrok TK z 16 grudnia 1997 roku, K 8/97, OTK ZU nr 5-6/1997, poz. 70.

Wyrok TK z 24 lutego 1999 roku, SK 4/98, OTK ZU nr 2/1999, poz. 24. Wyrok TK z 8 maja 2000 roku, SK 22/99, OTK ZU 2000, poz. 107.

Wyrok TK z 20 września 2001 roku, K 15/01, OTK ZU nr 8/2001, poz. 252.

Wyrok TK z 22 maja 2002 roku, K 6/02, OTK ZU 3A/2002, poz. 33.

Wyrok TK z 28 maja 2002 roku, P 10/01, OTK ZU 3A/2002, poz. 35.

Wyrok TK z 20 listopada 2002 roku, K 41/02, OTK ZU 6A/2002, poz. 83.

Wyrok TK z 17 maja 2005 roku, P 6/04, OTK ZU 5A/2005, poz. 50.

Wyrok TK z 8 września 2005 roku, P 17/04, OTK ZU 8A/2005, poz. 90.

Wyrok TK z 24 października 2005 roku, P 13/04, OTK ZU 9A/2005, poz. 102.

Wyrok TK z 21 lutego 2006 roku, K 1/05, OTK ZU nr 2/A/2006, poz. 18.

Wyrok TK z 1 kwietnia 2008 roku, SK 96/06, OTK ZU 3A/2008, poz. 40.

Wyrok TK z 28 października 2009 roku, Kp 3/09, OTK ZU 9A/2009, poz. 138.

Wyrok TK z 29 maja 2012 roku, SK 17/09, OTK ZU 5A/2012, poz. 53.

Wyrok TK z 4 listopada 2015 roku, K 1/14, OTK ZU 10A/2015, poz. 163. 


\section{INNE ORZECZENIA}

Wyrok SA w Białymstoku z 11 czerwca 2018 roku, III AUa 243/18, LEX nr 2550327.

Wyrok SN z 4 lipca 2007 roku, I UK 36/07, LEX nr 390123.

Wyrok SA w Łodzi - III Wydział Pracy i Ubezpieczeń Społecznych z 6 marca 2013 roku, III AUa 1148/12, Legalis nr 1033727.

Wyrok WSO Warszawa-Praga w Warszawie z 15 marca 2019 roku, VII U 372/18, LEX nr 2701469.

\section{INNE MATERIAEY}

Informacja Najwyższej Izby Kontroli o wynikach kontroli: Skuteczność działania systemu przechowywania dokumentacji osobowej i płacowej, Warszawa, wrzesień 2017, LGD.410.018.2016, nr ewid. 118/2017/P/16/064/LGD, https://www.nik.gov.pl/plik/id,15248,vp,17729.pdf.

Opinie prawne do poselskiego projektu ustawy o zmianie ustawy o emeryturach i rentach z Funduszu Ubezpieczeń Społecznych (druk nr 633) autorstwa J.M. Karolczak i B. Kłos, http://orka. sejm.gov.pl/rexdomk6.nsf/Opdodr?OpenPage\&nr=633.

Sprawozdanie z działalności Najwyższej Izby Kontroli w 2018 roku, https://www.nik.gov.pl/plik/id, 20101.pdf (dostęp: 9.11.2019).

Uzasadnienie do rządowego projektu ustawy o zmianie niektórych ustaw w związku ze skróceniem okresu przechowywania akt pracowniczych oraz ich elektronizacją, druk sejmowy nr 1995, VIII kadencja, http://www.sejm.gov.pl/Sejm8.nsf/druk.xsp?nr=1995. 